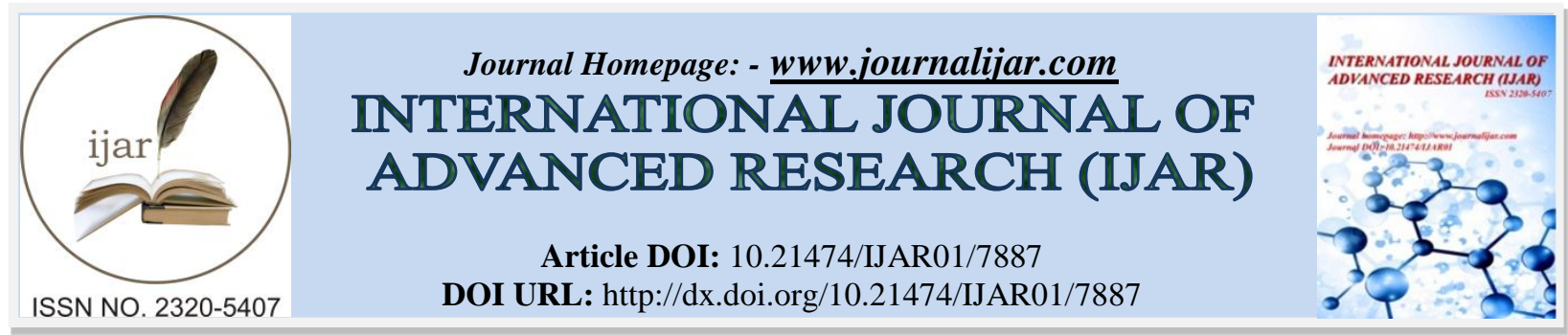

RESEARCH ARTICLE

\title{
EXTENT OF AWARENESS AND PRACTICES TOWARD IMPLEMENTATION OF REPUBLIC ACT 9003 IN THE MUNICIPALITY OF SANTA CRUZ, LAGUNA, PHILIPPINES.
}

Enrico R. Rivano, M.S.

\section{Manuscript Info}

\section{Manuscript History}

Received: 11 August 2018

Final Accepted: 13 September 2018

Published: October 2018

\section{Keywords:}

Solid waste management, biodegradable wastes, residual wastes, segregation, recycling, composting

\begin{abstract}
This descriptive research assessed the extent of awareness and practices toward implementation of the Republic Act 9003 in the Municipality of Santa Cruz, Province of Laguna, Philippines. Three (3) groups of respondents appraised the implementation of said law in the ten (10) sampled barangays. There were one hundred eighty (180) sample household residents, six (6) garbage collectors and sixteen (16) barangay officials, a total respondents of two hundred two (202) involved in the study. Frequency count, percentage, ranking and weighted mean were used in analyzing the data.

This study found out that the household residents' most common practices in disposing biodegradable waste are in feeding wastes to animal, bringing the wastes to the garbage collection point and burying the waste for backyard composting. On recyclable wastes, the most common practice is on selling wastes to ambulant buyers and on residual wastes, the most common practice is bringing them to garbage collection point. Residents are slightly aware on proper segregation and collection of solid waste. They are not aware on composting biodegradable waste material. However, they are fully aware on recycling solid wastes. The household residents moderately complied on proper segregation and collection of solid wastes. They did not comply on the composting of biodegradable waste, however, the household residents moderately complied in the recycling of solid wastes. It is recommended that the municipal government may review the Medium-Term Barangay Ecological Solid Waste Management Plan and to monitor the strict implementation and compliance to the implementing rules of Republic Act 9003.
\end{abstract}

Copy Right, IJAR, 2018,. All rights reserved.

\section{Introduction:-}

One of the major issues tackled in the Millennium Development Goal (MDG) is the urgency and relevance of improving our solid waste management practices. The world produces millions of tons of household garbage, industrial waste and sewage each year. The disposal of which has now become a major environmental problem.

Austria (2008) described waste as not just a garbage. It can also be seen as energy, water, food, air, transportation, landscaping, time and money. Most of the time, it is identified as an unwanted or undesired material left over the completion of a process or activity. It can exist as solid, liquid or gas. Waste management works toward the 3R's 
namely, reduction, reuse and recycling of materials. The concept of waste management, explained by Klassen (2009) involves the collection, removal, processing and disposal of materials considered as waste. Historically, developed nations have dealt with their waste by sending it to landfills or burning it in incinerators.

Every Asian country has a different background and characteristics in relation to material cycles and waste management practices. However, most countries have common targets of implementing 3R's and some countries are following the new concept of the sound material-cycle society. Like other developing countries, waste management, according to Atienza (2008), has become a major problem in the Philippines for the past decades. The rapid population growth, urbanization and modernization have resulted in the significant increase of waste generated especially in the urban cities of the country. This condition has created both environmental and health problems due to the inability of both local and national government units to implement proper waste management primarily because of scarce financial, human and technical resources.

Republic Act 9003 otherwise known as the Ecological Solid Waste Management Act of 2000 signed into law on January 26, 2001 embodies provisions for greater public and private participation towards sound waste management. It mandates the creation of National Solid Waste Management Commission (NSWMC) at the national level. The law, as cited by Gonzales (2010), also requires the formulation of guidelines and targets for solid wastes minimization through source reduction and resources such as composting, recycling, re-use and recovery. It retains primary enforcement and responsibility of solid waste management with local government units while establishing a cooperative effort among the national government and LGUs, NGOs and the private sector.

Santa Cruz is a first class urban municipality with a total land area of 3, 860 hectares. It is the capital town of the province of Laguna in the Philippines. According to the 2010 census, it has a population of 110,943 people.

Santa Cruz is situated on the banks of the Santa Cruz River which flows into the eastern part of Laguna de Bay. The town is bounded by the Bay on the north, by Lumban and Pagsanjan towns in the east, Pagsanjan and Magdalena towns in the south, and Pila in the west. It is 87 kilometers (54 mi) from Manila via Calamba. It is accessible by land from the nearby 28 municipalities and by water through Laguna de Bay from Manila and some Rizal towns.

Santa Cruz is considered as the service and commercial center on the eastern part of the province. The town is composed of five barangays in the Poblacion area and 21 classified urban barangays. Although relatively far from the immediate urbanizing influence of Metropolitan Manila, Santa Cruz continues to progress. Santa Cruz is also the seat of the provincial government since 1885, giving the municipality an additional administrative function over the entire province. It also functions as the service center for transportation, commerce, health, education, and other social services for the predominantly rural north-eastern municipalities of the province. Boosting the economy of the municipality are the incipient and fast-growing agribusiness industries such as livestock raising, horticulture and aquaculture. The town is composed of twenty-six (26) urban barangays. All barangays are being classified as urban. The development of Santa Cruz as the administrative, commercial, and service center of Laguna makes it accessible for all private and public vehicles going to nearby places particularly Pagsanjan, Pila, Calamba, Liliw, Paete Siniloan and Nagcarlan.

Solid waste management is not just a question of aesthetics. Lack of management of solid waste leads to serious risks to public health and to the environment, each risk having its own economic cost. There is also evidence that aesthetics - the appearance of a locality and the absence or presence of nuisance -influences behavior that can lead to pollution and impacts on health, as well as indirectly causing economic constraints. Hence, solid waste management is an issue that deserves to be taken seriously.

It is in this light that the researcher would like to evaluate the extent of awareness and practices toward implementation of Republic Act 9003 also known as the Ecological Solid Waste Management Act of 2000 in the Municipality of Santa Cruz, Laguna. Through this endeavor, the researcher hopes to contribute input to the initiatives of the local government of Santa Cruz, Laguna towards its objective of building sustainable communities and hazard free environment. 


\section{Objectives:-}

This study aimed to assess the extent of awareness and practices toward implementation of Republic Act 9003 also known as the Ecological Solid Waste Management Act of 2000 in the Municipality of Santa Cruz, Laguna, Philippines.

Specifically, it sought to:

1. Determine the practices of household residents in disposing solid waste materials classified into biodegradable wastes, recyclable wastes and residual wastes.

2. Evaluate as to what extent the household residents are aware of the solid waste management operations with respect to:

3. Proper segregation and collection of solid waste materials.

4. Composting biodegradable solid waste materials

5. Recycling of solid waste materials.

6. Evaluate as to what extent the household residents comply with the solid waste management operations.

7. Appraise the degree of seriousness of problems met by the household residents, municipal garbage collectors and barangay officials on health and sanitation along with the solid waste management operations.

\section{Methodology:-}

The study used the descriptive research method with survey questionnaire as the principal research instrument. Three (3) groups of respondents appraised the implementation of R.A. 9003 in the ten (10) sampled barangays in the municipality of Santa Cruz, Laguna as to practices of household residents in disposing solid waste materials classified into biodegradable, recyclable and residual wastes, extent of awareness and extent of compliance of household residents on the solid waste management operations with regards on the proper segregation and collection, composting biodegradable wastes and recycling of wastes materials. The degree of seriousness of the problems of the household residents on the solid waste management operations, the degree of seriousness of the problems met by municipal garbage collectors and the barangay officials were also analyzed.

This study involved one hundred eighty (180) sample household residents, six (6) garbage collectors and sixteen (16) barangay officials which are members of the Barangay Committee on Health, Sanitation and Solid Waste Management with a total of two hundred two (202) respondents. Frequency count, percentage, ranking and weighted mean were used in analyzing the data.

\section{Results And Discussion:-}

Practices of the Household Residents in Disposing Solid Waste Materials

The three (3) common practices of household residents in disposing their biodegradable wastes are:

1. Feeding the wastes to animals (150 out of 180 residents or $83.33 \%$ )

2. Bringing the wastes to the garbage collection area (129 out of 180 residents or $71.67 \%$ )

3. Burying the wastes in the backyard for composting ( 89 out of 180 residents or $49.44 \%$ )

The two (2) most common practices of household residents in disposing their recyclable wastes are:

1. Selling the wastes to ambulant buyers (176 out of 180 residents or $97.78 \%$ )

2. Bringing the wastes to the garbage collection point. (107 out of 180 residents or $59.44 \%$ )

The most common practice of household residents in disposing their residual wastes is by bringing them to the garbage collection point. (173 out of 180 residents of $96.11 \%$ )

Extent of Awareness of Household Residents on Solid Waste Management Operations

Generally, the household residents are fully aware (FA) of proper segregation and collection of Solid Waste especially with respect to:

1. Bringing out biodegradable and recyclable wastes on schedule collection time and day only to the garbage collection point for collection by the barangay as reflected by a mean of 2.90 .

2. "No segregation, No collection" policy of the municipal government as computed with a mean of 2.84 .

3. Segregating solid waste at source or at the household level as indicated by a mean of 2.64 .

4. Segregating wastes into three classification namely, biodegradable wastes, recyclable wastes and residual wastes before disposing as shown with a mean of 2.50 . 
Generally, the household residents are not aware (NA) of composting biodegradable wastes. They were only fully aware (FA) in terms of the benefits and use of compost as reflected by a mean of 2.89 and natural composting resulting to a mean of 2.86 .

As to the recycling of solid wastes, the household residents are generally fully aware (FA) of the operation particularly on:

1. Selling of recyclables to junk shops or to ambulant buyers as indicated by a mean of 3.00.

2. Handicrafts made from recyclables are good sources of livelihood as computer with a mean of 3.00.

3. Bringing recyclables to collection point in the barangay for sorting, processing and storing as specified by a mean of 2.71 .

Extent of Compliance of Household Residents on the Solid Waste Management Operation

On the proper segregation and collection of solid wastes, the household residents moderately complied resulting with a mean of 2.13. There are only three (3) items on which they fully complied and these are:

1. Bringing out the biodegradable and recyclable wastes in scheduled collection time and day only to the garbage collection point for collection by the barangay as reflected by a mean of 2.73 .

2. "No segregation, No collection" policy of the municipal government leading to a mean of 2.58 .

3. Segregating solid waste at source or at the household level as indicated by a mean of 2.45 .

1. Regarding compliance in composting biodegradable wastes, the household residents generally did not comply resulting with a mean of 1.20 , except on item which was moderately complied that is natural composting as reflected by a mean of 2.35 .

2. With regards to compliance on recycling of solid wastes, the household residents moderately complied quantified with a mean of 2.05 , except on one (1) item which was fully complied and this is the selling of recyclables to junk shops or to ambulant buyers as shown in a mean of 2.93 .

Problems Met By Respondents Along Solid Wastes Management Operations

Problems Met By Household Residents:

On proper segregation and collection of solid wastes, the household residents met a moderate serious problem as reflected by a mean of 1.93 , except on two (2) very serious problems particularly on:

1. No time or opportunity to listen or watch about segregation and collection of solid wastes aired in local radio or TV networks as calculated with a mean of 2.67 .

2. Absence of designated curbside areas for wastes in the barangay specified by a mean of 2.34 .

Regarding composting of solid wastes, the household problems generally met this as a moderately serious problem as reflected by a mean of 1.98 , except on three (3) very serious problems such as:

1. Lack of training on composting conducted by barangay and concerned agencies as indicated by a mean of 3.00.

2. Lack of knowledge on procedures on how to make composts as measured by a mean of 3.00 .

3. No time or opportunity to listen or watch about composting in local radio or TV station as calculated by a mean of 2.70 .

With respect to the problems met by the household residents on recycling of solid wastes, they met this as moderate serious problems indicated with a mean of 2.05 except on three (3) problems which are considered serious, such as:

1. No trainings conducted by barangays and concerned agencies regarding conversion of solid waste into new products as reflected by a mean of 3.00 .

2. Barangay has no material recovery facility (MRF) for collection of recyclable waste for sorting, processing and storing as quantified by a mean of 3.00 .

3. No time or opportunity to listen or watch about composting in local radio or TV station resulted from a mean of 2.46 .

The problems met by the municipal garbage collectors are not serious as calculated by a mean of 1.60 . However, three (3) problems were noted as moderately serious and these are:

1. mixed dumping of wastes at the garbage collection point by household residents as reflected by a mean of 2.00.

2. dumping of wastes by household residents not on proper schedule quantified by a mean of 2.00.

3. dumping of waste not on proper collection point as indicated by a mean of 2.00 . 
Generally, the barangay officials serving as members of the committee on Health, Sanitation and Solid Waste Management met a moderate serious problems on solid waste management operations as reflected by a mean of 1.86. However, four (4) items were noted as serious problems and these are:

1. Lack of training on composting and recycling conducted by the municipal government and the Environment Management Bureau indicated by a mean of 2.86 .

2. Early dumping of wastes by household residents at the garbage collection point as calculated with a mean of 2.43 .

3. Mixed dumping of wastes by household residents to the garbage collection point as measured by a mean of 2.43 .

4. Late collection of wastes by municipal garbage collectors as computed with a mean of 2.43 .

\section{Conclusions And Recommendations:-}

In light of the foregoing findings, this study arrived on the following conclusions that:

1. The household residents' most common practices in disposing biodegradable waste are in feeding the wastes to animals, bringing the wastes to the garbage collection point and burying the waste to backyard composting. On recyclable wastes, the most common practice is on selling wastes to ambulant buyers. On residual wastes, the most common practice is by bringing them to garbage collection point.

2. As far as the residents' awareness on solid waste management is concerned, they are fully aware on proper segregation and collection of solid wastes on the four areas of concern: bringing out biodegradable and recyclable wastes on schedule collection time and day to the garbage collection point for collection by the barangay, "No segregation, no collection" policy by the municipal government, segregating solid wastes at source or at the household level and segregating wastes into biodegradable, recyclable and residual waste before disposing. They are not aware on composting biodegradable waste materials. However, they are fully aware on recycling solid wastes.

3. The household residents in the ten (10) sampled barangays vary in the extent of their compliance on solid waste management operations. The household residents moderately complied on proper segregation and collection of solid wastes. They did not comply on the composting of biodegradable wastes. However, the household residents moderately complied in the recycling of solid wastes.

4. The household residents also met multifarious problems with respect to proper segregation and collection of solid wastes, composting and collection of solid wastes, composting of solid wastes, and recycling of solid wastes. Likewise, the municipal garbage collectors and barangay officials met several pressing problems with regard to solid waste management operations. With regards to household residents, they met moderately serious problems in proper segregation and collection of solid waste materials, composting of solid waste materials and on recycling of solid waste materials. Concerning the problems met by garbage collectors, no serious problems were met. In the case of barangay officials, moderate serious problems were met by them with regard to solid waste management operations in the municipality of Santa Cruz, Laguna.

Committed towards future directions, the following recommendations are proposed:

1. It is recommended that the municipal government of Santa Cruz, Laguna, particularly the Municipal Solid Waste Management Board, further review the proposed Medium Term Barangay Ecological Solid Waste Management Plan. The review and revisions to be made could be a basis in formulating the Municipal and Barangay Ecological Solid Waste Management Plan in response to the challenge of effectively and sustainably managing the municipal increasing solid waste in compliance to the requirements of R.A. 9003.

2. It is recommended that the municipal government officials, in coordination with concerned agencies of the government, sponsor a training program to address the present solid waste management problems in the municipal and barangay levels.

3. It is recommended that the municipal government of Santa Cruz, Laguna, through its Solid Waste Management Division/Unit, enhance and maintain the municipal solid waste management operations.

4. The municipal government, through its Solid Waste Management Division/Unit, to monitor the strict implementation and compliance of Ecological Solid Waste Management activities in the barangay levels vis-àvis barangay plans formulated and strengthen the EIC on segregation at source and composting.

5. It is also recommended that the municipal government in collaboration with different institutions such as the Environment and Management Bureau, NGO's and other funding agencies to provide subsidy for the establishment of the Material Recovery Facilities (MRF) in the different clustered barangays. 
6. Municipal ordinances relative to solid waste management should be localized to the barangays. Local leaders should make sure that they are firm and consistent in implementing the policies to ensure that the program experiences success.

7. There are other alternative technologies that can help address and mitigate the problems and threats to sustainable solid waste management. Partnerships, linkages and networking with the private sectors, other LGU's, NGO's And other national government agencies for capacity enhancement and development are very much needed, to provide assistance in the proper management of biodegradable, non-biodegradable wastes, recyclable wastes, including toxic and special wastes.

\section{Reference:-}

1. Aarons, G.A. (2006). Transformational and Transactional Leadership Association with Attitudes toward Evidence-Based Practices. Psychiatric Services Publishing Co.

2. Atienza, V. (2008). Breakthroughs in Solid Waste Management: Lessons from selected Municipalities and Barangays in the Philippines. Asian Review of Public Administration. Volume X, No. 2

3. Austria, J. (2008). Impact of Solid Waste Management Act of 2000 towards Sustainable Hazard Free Environment. Journal of Ecological Sciences. Volume 4, Issue 3.

4. Cabigan, M., Rosales B., and Vibora N., (2014). An Assessment of the Community Needs in Twenty-Three Barangays of Santa Cruz, Laguna. Laguna State Polytechnic University Research and Development Journal. Volume 8

5. Clayton, G. (2007). Economic Principles and Practices. Jones and Barlett's Publishers House Inc.

6. Gonzales D.E. and Evardone, J. (2010). Compliance of LGUs to R.A. 9003: A benchmark for Quality of Life in the Countryside. Journal on Governance and Accountability. Asian Institute of Management. Volume 2, Issue 3

7. Klassen, R. (2009). Integrating Environmental Issues into the Mainstream: An Agenda for Research in Operations Management. Journal of Operations Management. Volume 17, p. 575-598.

8. Hall, S. (2012). The Descriptive Method of Research Design. Retrieved from http://www.ehow.com how 7905125 descriptive-method-research-design.html

9. Icban Jr., C. (2009). Improving the Working Lives of People Everywhere. Philippine Panorama. Volume 38, Number 3

10. Ramasang, S. (2006). Total Quality Management. Mc-Graw Hill Publishing Company. 